\title{
Effect of Radioactive Minerals Potentiality and Primordial Nuclei Distribution on Radiation Exposure Levels within Muscovite Granite, Wadi Nugrus, Southeastern Desert, Egypt
}

\author{
S. F. Hassan'1, M. A. M. Mahmoud', M. A. E. Abd El-Rahman' ${ }^{2}$ \\ ${ }^{1}$ Nuclear Materials Authority, Cairo, Egypt \\ ${ }^{2}$ Military Technical College, Cairo, Egypt \\ Email: hoodageo@yahoo.com
}

Received 23 January 2016; accepted 20 March 2016; published 23 March 2016

Copyright $@ 2016$ by authors and Scientific Research Publishing Inc.

This work is licensed under the Creative Commons Attribution International License (CC BY). http://creativecommons.org/licenses/by/4.0/

(c) ()

\section{Abstract}

The studied area at Wadi Nugrus, Southeastern Desert, Egypt, is located between lat. $24^{\circ} 41^{\prime} 00^{\prime \prime}$ and $24^{\circ} 41^{\prime} 35^{\prime \prime} \mathrm{N}$ and long. $34^{\circ} 36^{\prime} 47^{\prime \prime}$ and $34^{\circ} 37^{\prime} 09^{\prime \prime} \mathrm{E}$. The rock types are represented by layered metagabbros, biotite schists, gneisses, granodiorites, and Muscovite granites. The muscovite granite of Wadi Nugrus, is small exposure in size $\left(\sim 5.0 \mathrm{~km}^{2}\right)$, emplaced along NW-SE trend, with about $0.5-4.5 \mathrm{Km}$ in length and $100-250 \mathrm{~m}$ in width and intruding the biotite schists. The studied muscovite granite is composed mainly of plagioclases, potash feldspars, quartz, biotite and muscovite. The recorded minerals assemblage can be classified into secondary U-minerals (uranophane and meta-autunite), U-bearing minerals (uranothorite and columbite) and accessory minerals (zircon, flourite, allanite, zinnwaldite and hematite). The $\mathrm{U} / \mathrm{eU}$ is more unity where, the measured chemical uranium is higher than the measured equivalent uranium in the most analyzed samples especially in trenches, which reflect disequilibrium state. The activity concentrations range from 251.72 to $1096.2 \mathrm{~Bq} \cdot \mathrm{kg}^{-1}$ for ${ }^{232} \mathrm{Th}$, from 494 to $2593.5 \mathrm{~Bq} \cdot \mathrm{kg}^{-1}$ for ${ }^{226} \mathrm{Ra}$, and from 1314.6 to $1846.7 \mathrm{~Bq} \cdot \mathrm{kg}^{-1}$ for ${ }^{40} \mathrm{~K}$. The obtained radiological data show that the average internal and external hazard indices are 9.11 and 5.78, respectively which are more than unity and highly exceeding the permissible limits (International Commission on Radiation Protection, ICRP). The internal and external hazards are mainly due to ${ }^{226} \mathrm{Ra}$ nuclei while the absorbed dose rate $(\mathrm{nGy} / \mathrm{h})$ is related to ${ }^{232} \mathrm{Th}$ nuclei. The contributions of the three nuclei in the total absorbed dose rates and internal and external hazardous, for ${ }^{226} \mathrm{Ra}$, it contributes by $72 \%$ in $\mathrm{H}_{\text {in, }} 57 \%$ in $\mathrm{H}_{\mathrm{ex}}$ and $55 \%$ of $\mathrm{D}_{\mathrm{R}}$, for ${ }^{232} \mathrm{Th}$ it contributes by $24 \%$ in $H_{i n}, 37 \%$ in $H_{e x}$ and $36.9 \%$ of $D_{R}$, while for ${ }^{40} \mathrm{~K}$ it contributes by $4.1 \%$ in $H_{\text {in, }}$, $6.4 \%$ in $\mathrm{H}_{\mathrm{ex}}$ and $8.1 \%$ of $\mathrm{D}_{\mathrm{R}}$. 


\section{Keywords}

\section{Muscovite, Peraluminous, Uranium, Radiation Exposure Levels, Radon Concentration}

\section{Introduction}

Nugrus-Sikait area constitutes a part of the Arabian Nubian Shield bordering to the major shear zone known as Nugrus thrust fault [1], or Nugrus strike-slip fault [2] and Sha'it-Nugrus shear zone. This shear zone separates high-temperature metamorphic rocks of the Hafafit complex in the SW from mainly low-grade ophiolitic and arc volcanic assemblages known as Ghadir group [3]. The Nugrus thrust runs along the upper part of Wadi Sikait in NW direction till the southern tip of Gable Ras Sha'it, then swings to a south westward direction along Wadi Sha'it west of Gable Migif. The Migif-Hafafit gneisses comprise the foot wall of the Nugrus thrust, while the Ghadir group comprises its hanging wall [4].

Generally, the leucogranites are widely distributed all over the Egyptian Precambrian Shield, constituting approximately $10 \%$ of its plutonic assemblages [5]-[7].

Peraluminous leucogranites are divided into two groups; the muscovite-bearing granites and the cordieritebearing granites. The majority of the two groups are formed by partial melting of the crustal rocks. The forming of peraluminous leucogranites does not depend only on the nature of the sources, but is also controlled by the physical parameters of partial melting and consequently by the way anatexis of a thickened crust is enhanced. The peraluminous leucogranites can probably be formed during the same geodynamic event and possibly from the source, but they are not different members of the same magmatic suite [8].

Radionuclides in our environment are of three general types: primordial, cosmogenic, and anthropogenic (manmade). Natural radionuclides are present in all rocks in varying amounts depending on their concentration levels in source rock materials. It is known that the radionuclides ${ }^{238} \mathrm{U},{ }^{235} \mathrm{U}$ and ${ }^{232} \mathrm{Th}$ may become incorporated in igneous materials when they are originally formed from the molten state [9].

Natural radionuclides in rocks and soil generate a significant component of the background radiation exposure to human beings, depend on the composition of the soils and rocks in which they are contained a significant contribution to total dose from natural sources which come from terrestrial radionuclides such as ${ }^{238} \mathrm{U},{ }^{232} \mathrm{Th}$ and ${ }^{40} \mathrm{~K}$ present in soil [10]-[12].

Since these radionuclides are not uniformly distributed, the knowledge of their distribution in soil and rocks plays an important role in radiation protection and measurement [13]. As radiation of natural origin is responsible for most of the total radiation exposure, knowledge of the dose received from natural sources is very important for not only of its effects on health but also of the incidence of other radiation from man-made sources [14].

There have been many surveys to determine the background levels of the radionuclides. All of these measurements indicate that gamma-emitting radionuclides in ${ }^{226} \mathrm{Ra},{ }^{232} \mathrm{Th}$ series and ${ }^{40} \mathrm{~K}$, make approximately equal contributions to the externally incident gamma radiation dose to individuals in typical situations both indoor and outdoor [15].

Measurement of natural radioactivity in rocks is crucial in implementing precautionary measures whenever the source is found to exceed the recommended limit; it determines the amount of change of the natural background activity with time as a result of any radioactive release. The levels due to the terrestrial background radiation are related to the types of rock from which the soils originate. Higher radiation levels are associated with igneous rocks such as granite and lower levels with sedimentary rocks. There are some exceptions however, since some shales and phosphate rocks have a relatively high content of radionuclides [16].

\section{Aim of Work}

This work aims to study the effect of radioactive minerals and distributions and natural radioactive nuclei distributions on the radiation exposure levels in muscovite granite at Wadi Nugrus area.

\section{Geology}

The studied area is located between latitudes $24^{\circ} 41^{\prime} 00^{\prime \prime}$ and $24^{\circ} 41^{\prime} 35^{\prime \prime} \mathrm{N}$ and longititudes $34^{\circ} 36^{\prime} 47^{\prime \prime}$ and $34^{\circ} 37^{\prime} 09^{\prime \prime E}$., 
the lithology is arranged tectono-stratigraphically beginning with the oldest as follows; layerd metagabbro, biotite schist, gneisses rocks, granodiorite and muscovite granite (Figure 1).

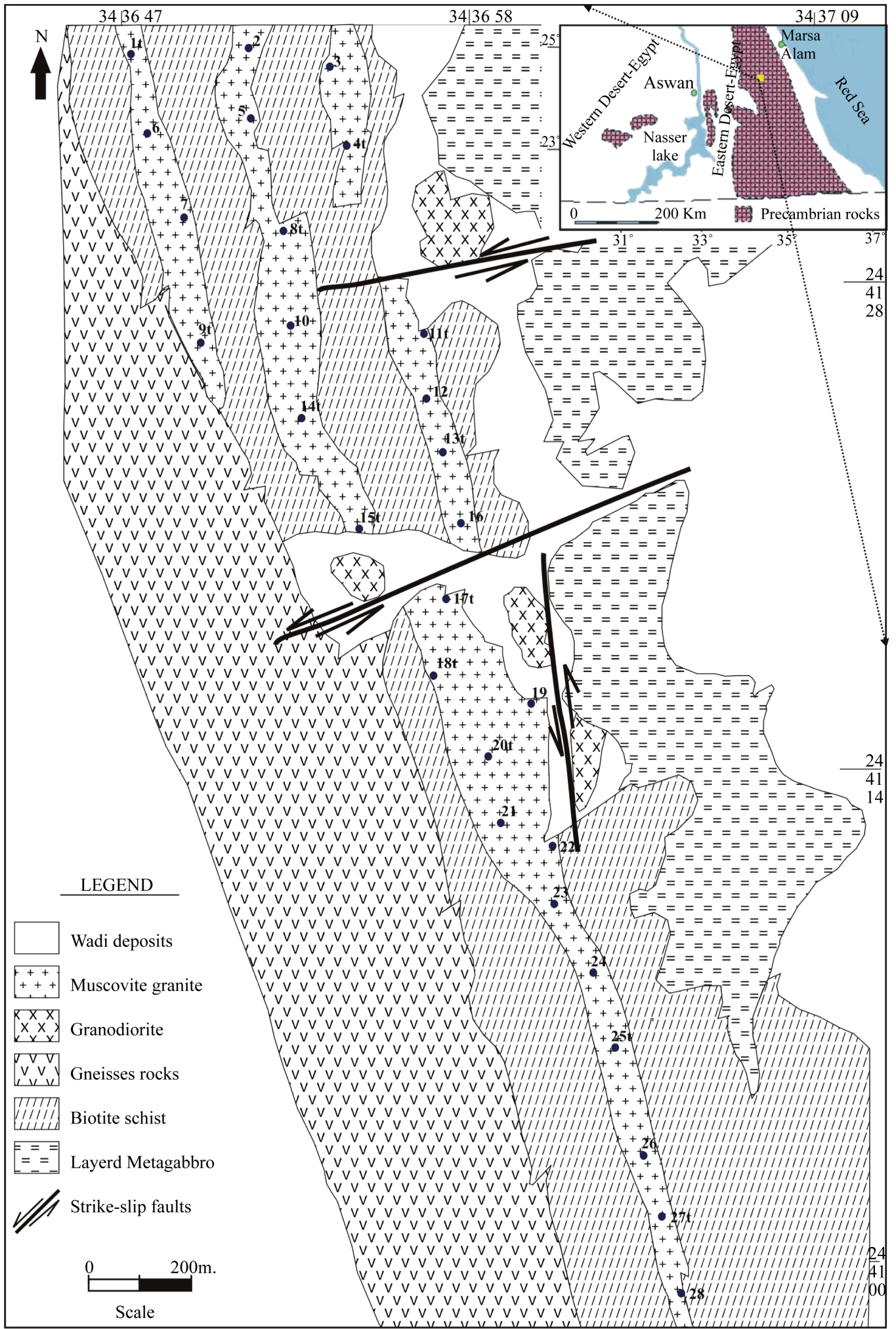

Figure 1. Geologic map of the studied area at Wadi Nugrus, South-eastern Desert, Egypt (modified after [17] [18]). 
Wadi Nugrus was studied by many authors, e.g., [17]-[19], which they are concluded that the leucogranites are peraluminous in nature and contain some spots of radioactive anomalies.

The muscovite granite exposure at Wadi Nugrus is small in size $\left(\sim 4.0 \mathrm{~km}^{2}\right)$ and emplaced along NW-SE trend (Figure 2(a)), reached about $4 \mathrm{Km}$ length and $100-250 \mathrm{~m}$ width. It is dissected by the major sets of joints and faults trending N-S and NE-SW with steep angle of dip. The muscovite granite has white colour, but at some outer contacts, it is highly weathered, reddish color due to the hematitization or whitish due to kaolinization. The studied muscovite granite is intruding the biotite schists with the foliation of the host rocks at high angle (Figure 2(b)). It is posseses some xenoliths from the host rocks. NE-SW and N-S strike slip faults dislocate the studied granite with common displacement.

Petrographically, the studied muscovite granite revealed the presence of varying amounts of quartz, feldspar, muscovite and biotite, as well as accessory minerals assemblage including zircon, allanite, garnet and fluorite (Figure 2(c) and Figure 2(d)). The main hosts for U and Th are zircon, allanite, and members of the uranophaneuranothorite solid solution series that are associated with biotite and muscovite. The muscovite granite also shows evidence of post-crystallization hydrothermal alteration in thin section. The hydrothermal mineral assemblage includes hematite, chlorite, fluorite, clay minerals, quartz, carbonate, and sausserite.

Mineralogically, the studied muscovite granite are characterized by several mineral assemblages especially; secondary U-minerals (uranophane and meta-autunite) which occur as microfractures infilling or joint surface coating, U-bearing minerals (uranothorite) [17]-[19] and accessory minerals (columbite, zircon, flourite, zinnwaldite and hematite).

\section{Methodology}

Twenty eight stations (included 14 trenches), were chosen and covered the studied muscovite granite at Wadi Nugrus (Figure 1), to spectrometrical and radioactivity levels investigations.
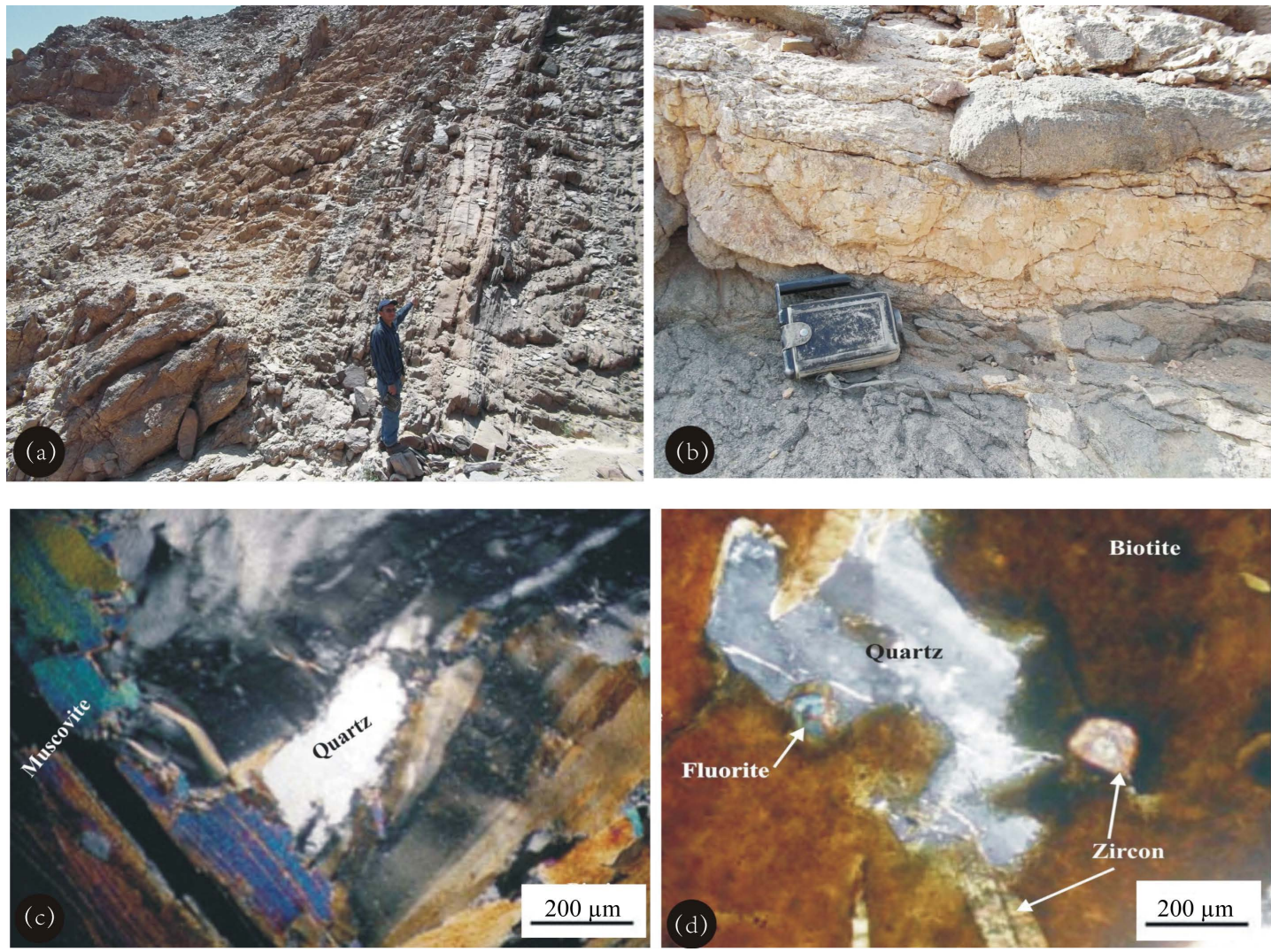

Figure 2. Studied muscovite granite showing the following photographs; (a) Low topographic muscovite granite trending NW-SE, (b) Muscovite granite (white) intruded in biotite schist (gray), (c) Flakes of muscovite with undulose quartz crystals, (d) Zircon and fluorite enclosed in biotite flakes. 
A mass of $200 \mathrm{~g}$ of each sample was packed in special plastic cup then closed and tightly sealed using cellotape. The containers were labeled appropriately and then kept for 30 days.

The concentrations of radionuclides $\left({ }^{226} \mathrm{Ra},{ }^{232} \mathrm{Th}\right.$ and $\left.{ }^{40} \mathrm{~K}\right)$ in each prepared samples were determined using NaI gamma ray spectrometer by counting each sample for $1000 \mathrm{sec}$, the values of eU, eTh, eRa, in ppm, and K, in\%. The activity of ${ }^{226} \mathrm{Ra}$ was evaluated from gamma-ray lines of ${ }^{214} \mathrm{Bi}$ at $609.3,1120.3 \mathrm{kev}$ and ${ }^{214} \mathrm{~Pb}$ at 351 kev, while the activity of ${ }^{232}$ Th was evaluated from gamma-ray lines of ${ }^{228} \mathrm{Ac}$ at 338.4, 911.1and $968.9 \mathrm{kev}$. The activity of ${ }^{40} \mathrm{~K}$ was determined directly from its $1460.8 \mathrm{kev}$ gamma-ray line [20]-[22]. In general, the radioelement concentrations in rocks are expressed in mass concentrations of $\mathrm{K} \%,{ }^{238} \mathrm{U},{ }^{232} \mathrm{Th}$ and ${ }^{226} \mathrm{Ra}$. According to IAEA [23], the conversion of radioelement concentrations in rocks to specific activity are given as $313 \mathrm{~Bq} / \mathrm{kg}$ for of $1 \% \mathrm{~K}, 12.35 \mathrm{~Bq} / \mathrm{kg}$ for $1 \mathrm{ppm}$ of ${ }^{238} \mathrm{U}$ or ${ }^{226} \mathrm{Ra}$ and $4.06 \mathrm{~Bq} / \mathrm{kg}$ for $1 \mathrm{ppm}$ of ${ }^{232} \mathrm{Th}$.

The radon gas concentration were measured in the field by using cup techniques employing SSNTDs detectors, in which a plastic cup of about $12 \mathrm{~cm}$ height, $7 \mathrm{~cm}$ diameter at the open mouth and $5.4 \mathrm{~cm}$ diameter at the bottom, is fitted with a $1.5 \times 1.5 \mathrm{~cm}^{2} \mathrm{CR}-39$ type detector attached to its inside bottom. The open mouth of the cup is covered with filter, which permits radon gas only to enter the cup and prevents the entrance of radon daughters. The CR-39 plastic used in this work is $500 \mu \mathrm{m}$ in thickness, manufactured by Pershore Molding Limited, England. The cups was then immersed in the ground for 30 day as an exposure time, then collected, etched under optimum conditions and counted using an optical microscope with a total magnification of $400 \mathrm{X}$ [24]. The track density $\left(\mathrm{T} \cdot \mathrm{cm}^{-2} \cdot \mathrm{d}^{-1}\right)$ and the calibration factor (CF) of the used CR-39 detector were obtained as value, $\mathrm{CF}=0.2153 \pm 0.035\left(\mathrm{~T} \cdot \mathrm{cm}^{-2} \cdot \mathrm{d}^{-1} / \mathrm{pCi} / \mathrm{l}\right)[25]$.

The calculated radon gas concentration $(\mathrm{pCi} / \mathrm{l})$ at each monitoring station is obtained as follows:

$$
\mathrm{C}_{\mathrm{Rn}}=\frac{\rho}{\mathrm{K}}(\mathrm{pCi} / \mathrm{l})
$$

where, $\mathrm{C}_{\mathrm{Rn}}$ the calculated radon in $(\mathrm{pCi} / \mathrm{l}), \rho$ is the track density per $\mathrm{cm}^{2}$ per day detector, $\mathrm{K}$ the calibration factors $\left(\mathrm{T} \cdot \mathrm{cm}^{-2} \cdot \mathrm{d}^{-1} / \mathrm{pCi} / \mathrm{l}\right)$.

The studied samples were taken for chemical and gamma spectrometric analysis in the Nuclear Materials Authority (NMA) and Military Technical College laboratories to determine the equivalent ${ }^{238} \mathrm{U},{ }^{226} \mathrm{Ra},{ }^{232} \mathrm{Th}$ and ${ }^{40} \mathrm{~K}$ as well as chemical analysis of $U$ and $T h$.

\section{Radiometry}

\subsection{The Distribution and Relation of $\mathrm{U}_{\mathrm{ch}} / \mathrm{eU}$}

The $\mathrm{U}_{\mathrm{ch}} / \mathrm{eU}$ is equal to the ratio of the chemically determined uranium $\left(\mathrm{U}_{\mathrm{ch}}\right) /$ radiometrically measured uranium $(\mathrm{eU})$. If the $\mathrm{U}_{\mathrm{ch}} / \mathrm{eU}$ is approximately unity or more, it indicates addition or removal of uranium, respectively [26]. From Table 1, and the bar-diagram (Figure 3), the studied Muscovite granite of Wadi Nugrus shows that $\mathrm{U}_{\mathrm{ch}} / \mathrm{eU}$ is more unity and the measured $\mathrm{U}_{\mathrm{ch}}$ is higher than the measured eU in the most analyzed samples specially taken from trenches, which reflects disequilibrium due to the addition of uranium minerals.

\subsection{Radioelement Concentrations}

The concentration of the measured radioelements eU, eRa eTh, in (ppm) and K\% beside the specific activity of these radionuclide calculated using the previously mentioned conversion factor are listed in Table 2 . From this table, the measurements of the collected samples were ranged from 40 - 210., 21 - 120., $62-270 \mathrm{ppm}$ and 4.2\% - 5.9\%, for eRa, eU, eTh, (ppm) and K\% respectively, with average values of $99.86 \pm 46.20(\mathrm{ppm}), 51.07 \pm$ 22.31 (ppm), $135.61 \pm 52.63$ (ppm) and $4.96 \pm 0.54$ (\%) respectively. It is noted that the measured values are greater than the overall average world values for theses nuclei. A small range and small value for the standard deviation that measured for ${ }^{40} \mathrm{~K}$ nuclei indicates that there is some uniform distribution for this nuclide inside the studied area.

\subsection{Activity Concentrations}

Table 2 shows the activity concentrations for the measured nuclei in the studied area , they ranged from 494.0 $2593.5 \mathrm{~Bq} \cdot \mathrm{kg}^{-1}$ for ${ }^{226} \mathrm{Ra}, 345.8-1482 \mathrm{~Bq} \cdot \mathrm{kg}^{-1}$ for the ${ }^{238} \mathrm{U}, 251.72-1096.2$ for ${ }^{232} \mathrm{Th}$ and 1314.6 - 1846.7 for the ${ }^{40} \mathrm{~K}$, with an average values of $1233.24 \pm 570.53 \mathrm{~Bq} \cdot \mathrm{kg}^{-1}, 630.73 \pm 275.50 \mathrm{~Bq} \cdot \mathrm{kg}^{-1}, 550.57 \pm 213.69 \mathrm{~Bq} \cdot \mathrm{kg}^{-1}$, 
Table 1. Results of U-spectrometric $(\mathrm{eU})$, eTh and $\mathrm{U}_{\mathrm{ch}}$ chemical analysis, U/eU ratios in the studied muscovite granite of Wadi Nugrus.

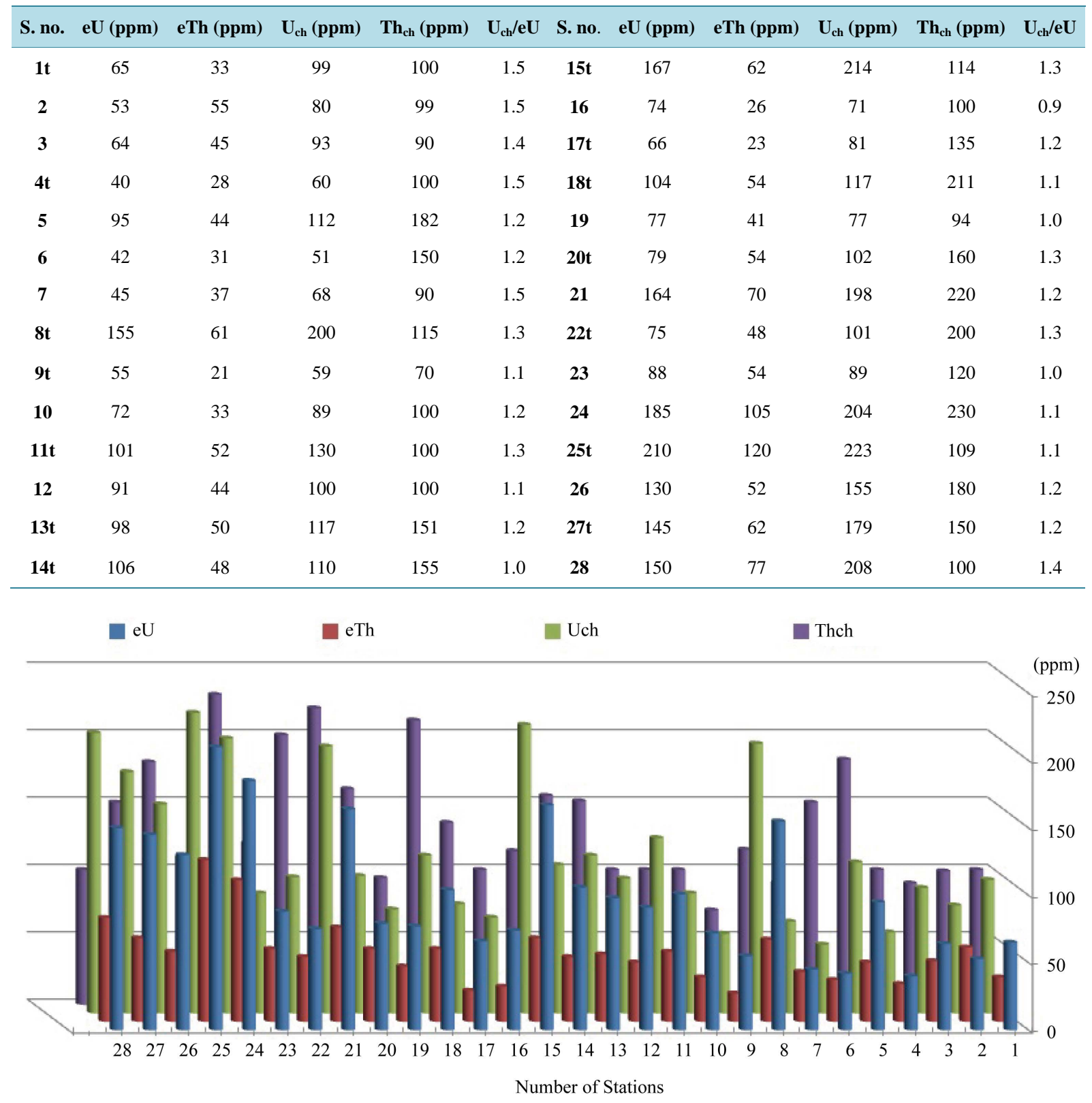

Figure 3. Bar-diagram showing the distribution of eU, eTh, $\mathrm{U}_{\mathrm{ch}}$ and $\mathrm{Th}_{\mathrm{ch}}$ in the studied muscovite granite of Wadi Nugrus.

and $1552.70 \pm 167.87 \mathrm{~Bq} \cdot \mathrm{kg}^{-1}$ respectively. The general observation indicates that the all studied samples, has the highest activity concentration of ${ }^{40} \mathrm{~K}$. All the average values were higher than the world wide average activity concentrations of ${ }^{40} \mathrm{~K},{ }^{226} \mathrm{Ra}$ and ${ }^{232} \mathrm{Th}$ which are 370,30 and $25 \mathrm{~Bq} \cdot \mathrm{kg}^{-1}$, respectively [14]. The ${ }^{40} \mathrm{~K}$ activity varied widely due to heterogeneous rocks characteristics.

The Presence of such high radioactivity may be attributed to the presence of relatively increased amount of secondary uranium minerals and accessory minerals such as zircon, iron oxides, fluorite and other radioactive related minerals. These minerals play an important role in controlling the distribution of uranium and thorium.

The correlation between the measured three nuclei were plotted in Figure 4, which shows that a very good correlations between ${ }^{226} \mathrm{Ra}$ and ${ }^{232} \mathrm{Th}$ with correlation coefficient of 0.822 , whereas a poor correlations between ${ }^{232}$ Th with ${ }^{40} \mathrm{~K}$ and ${ }^{226} \mathrm{Ra}$ with ${ }^{40} \mathrm{~K}$, with correlation coefficients of 0.063 and 0.089 respectively. 
Table 2. Track density ( $\left.\mathrm{t} / \mathrm{cm}^{2} / \mathrm{d}\right)$, Rn gas concentration (Pci/l), radioelement's concentration and specific activity of the studied muscovite granite, Wadi Nugrus.

\begin{tabular}{|c|c|c|c|c|c|c|c|c|c|c|}
\hline & Track den- & Radon concentra- & eRa & $\mathbf{e U}$ & eTh & $\mathbf{K}$ & eRa & $\mathbf{e U}$ & eTh & $\mathbf{K}$ \\
\hline & $\left(\mathrm{T} / \mathrm{Cm}^{2} / \mathrm{d}\right)$ & (Pci/l) & (ppm) & (ppm) & (ppm) & $(\%)$ & $\left(B q \cdot \mathrm{kg}^{-1}\right)$ & $\left(\mathrm{Bq} \cdot \mathrm{kg}^{-1}\right)$ & $\left(\mathrm{Bq} \cdot \mathrm{kg}^{-1}\right)$ & $\left(\mathrm{Bq} \cdot \mathrm{kg}^{-1}\right)$ \\
\hline $1 t$ & $26.82 \pm 1.57$ & $124.56 \pm 7.30$ & 65 & 33 & 78 & 4.2 & 802.75 & 407.55 & 316.68 & 1314.6 \\
\hline 2 & $27.70 \pm 2.08$ & $128.67 \pm 9.68$ & 53 & 55 & 80 & 5.2 & 654.55 & 679.25 & 324.8 & 1627.6 \\
\hline 3 & $28.81 \pm 2.48$ & $133.83 \pm 11.53$ & 64 & 45 & 75 & 4.5 & 790.4 & 555.75 & 304.5 & 1408.5 \\
\hline $4 t$ & $17.30 \pm 1.68$ & $80.34 \pm 7.82$ & 40 & 28 & 74 & 5.2 & 494 & 345.8 & 300.44 & 1627.6 \\
\hline 5 & $29.51 \pm 2.77$ & $137.05 \pm 12.85$ & 95 & 44 & 108 & 5.1 & 1173.25 & 543.4 & 438.48 & 1596.3 \\
\hline 6 & $33.38 \pm 3.25$ & $155.02 \pm 15.10$ & 42 & 31 & 93 & 4.5 & 518.7 & 382.85 & 377.58 & 1408.5 \\
\hline 7 & $40.76 \pm 3.92$ & $189.32 \pm 18.20$ & 45 & 37 & 112 & 4.9 & 555.75 & 456.95 & 454.72 & 1533.7 \\
\hline $8 t$ & $89.20 \pm 6.01$ & $414.29 \pm 27.93$ & 155 & 61 & 179 & 5.6 & 1914.25 & 753.35 & 726.74 & 1752.8 \\
\hline $9 t$ & $26.76 \pm 3.32$ & $124.29 \pm 15.44$ & 55 & 21 & 62 & 4.5 & 679.25 & 259.35 & 251.72 & 1408.5 \\
\hline 10 & $24.61 \pm 2.58$ & $114.30 \pm 12.00$ & 72 & 33 & 99 & 4.4 & 889.2 & 407.55 & 401.94 & 1377.2 \\
\hline $11 t$ & $33.06 \pm 4.34$ & $153.57 \pm 20.14$ & 101 & 52 & 149 & 5.4 & 1247.35 & 642.2 & 604.94 & 1690.2 \\
\hline 12 & $40.67 \pm 3.97$ & $188.92 \pm 18.43$ & 91 & 44 & 116 & 4.8 & 1123.85 & 543.4 & 470.96 & 1502.4 \\
\hline $13 t$ & $51.18 \pm 6.07$ & $237.69 \pm 28.18$ & 98 & 50 & 156 & 5.1 & 1210.3 & 617.5 & 633.36 & 1596.3 \\
\hline $14 t$ & $44.53 \pm 5.76$ & $206.81 \pm 26.76$ & 106 & 48 & 144 & 5.8 & 1309.1 & 592.8 & 584.64 & 1815.4 \\
\hline $15 t$ & $95.58 \pm 7.34$ & $443.93 \pm 34.08$ & 167 & 62 & 196 & 5.7 & 2062.45 & 765.7 & 795.76 & 1784.1 \\
\hline 16 & $32.17 \pm 3.56$ & $149.40 \pm 16.55$ & 74 & 26 & 81 & 5.1 & 913.9 & 321.1 & 328.86 & 1596.3 \\
\hline $17 t$ & $36.56 \pm 7.18$ & $169.80 \pm 33.33$ & 66 & 23 & 70 & 4.6 & 815.1 & 284.05 & 284.2 & 1439.8 \\
\hline $18 t$ & $57.39 \pm 5.58$ & $266.56 \pm 25.91$ & 104 & 54 & 148 & 5.4 & 1284.4 & 666.9 & 600.88 & 1690.2 \\
\hline 19 & $58.85 \pm 6.13$ & $273.32 \pm 28.46$ & 77 & 41 & 107 & 4.2 & 950.95 & 506.35 & 434.42 & 1314.6 \\
\hline $20 t$ & $62.95 \pm 4.88$ & $292.36 \pm 22.66$ & 79 & 54 & 172 & 4.4 & 975.65 & 666.9 & 698.32 & 1377.2 \\
\hline 21 & $94.17 \pm 7.36$ & $437.37 \pm 34.19$ & 164 & 70 & 217 & 5.7 & 2025.4 & 864.5 & 881.02 & 1784.1 \\
\hline $22 t$ & $39.50 \pm 4.41$ & $183.45 \pm 20.48$ & 75 & 48 & 127 & 4.7 & 926.25 & 592.8 & 515.62 & 1471.1 \\
\hline 23 & $47.45 \pm 2.96$ & $220.38 \pm 13.77$ & 88 & 54 & 165 & 5.1 & 1086.8 & 666.9 & 669.9 & 1596.3 \\
\hline 24 & $91.00 \pm 4.86$ & $422.67 \pm 22.56$ & 185 & 105 & 207 & 4.8 & 2284.75 & 1296.75 & 840.42 & 1502.4 \\
\hline $25 t$ & $90.34 \pm 7.50$ & $419.60 \pm 34.81$ & 210 & 120 & 270 & 4.2 & 2593.5 & 1482 & 1096.2 & 1314.6 \\
\hline 26 & $56.53 \pm 4.67$ & $262.57 \pm 21.69$ & 130 & 52 & 155 & 5.9 & 1605.5 & 642.2 & 629.3 & 1846.7 \\
\hline $27 t$ & $64.83 \pm 6.34$ & $301.12 \pm 29.46$ & 145 & 62 & 185 & 4.3 & 1790.75 & 765.7 & 751.1 & 1345.9 \\
\hline 28 & $72.55 \pm 7.55$ & $336.96 \pm 35.04$ & 150 & 77 & 172 & 5.6 & 1852.5 & 950.95 & 698.32 & 1752.8 \\
\hline Aver. & $50.50 \pm 4.65$ & $234.58 \pm 21.58$ & 99.86 & 51.07 & 135.61 & 4.96 & 1233.24 & 630.73 & 550.57 & 1552.70 \\
\hline St.dv. & $23.94 \pm 1.87$ & $111.20 \pm 8.70$ & 46.20 & 22.31 & 52.63 & 0.54 & 570.53 & 275.50 & 213.69 & 167.87 \\
\hline
\end{tabular}




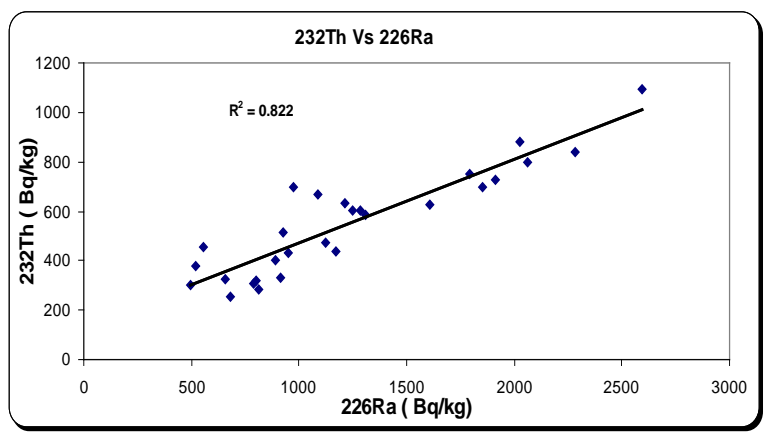

(a)

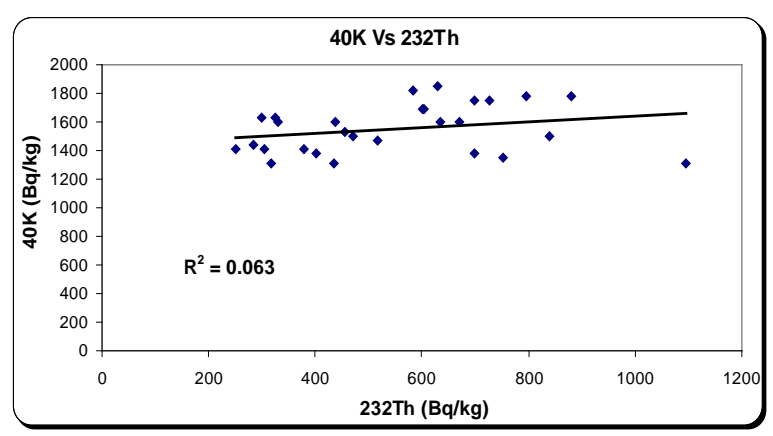

(b)

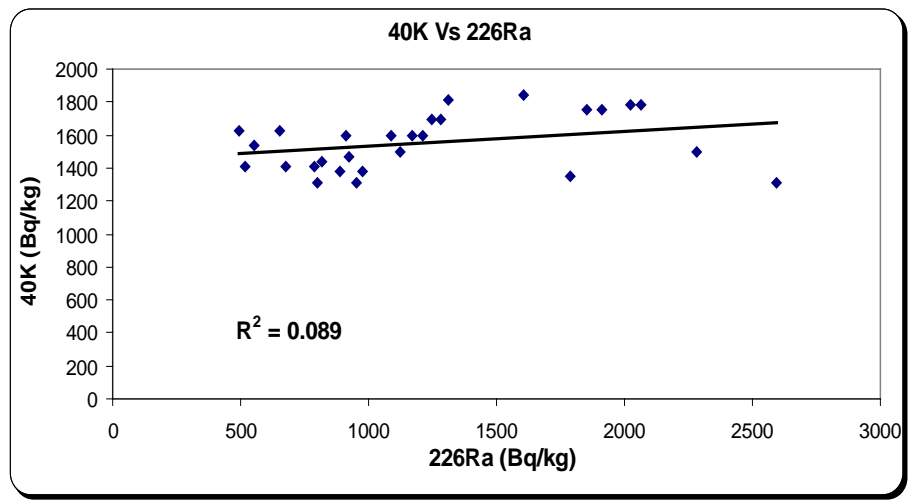

(c)

Figure 4. Binary diagrams showing the correlation between; (a) ${ }^{226} \mathrm{Ra}$ vs. ${ }^{232} \mathrm{Th}$, (b) ${ }^{232} \mathrm{Th}$ vs. ${ }^{40} \mathrm{~K}$, and (c) ${ }^{226} \mathrm{Ra}$ vs. ${ }^{40} \mathrm{~K}$, in the studied muscovite granite, Wadi Nugrus.

Figure 5 shows the graphical representations for the average activity distributions of the radionuclides ${ }^{238} \mathrm{U}$, ${ }^{226} \mathrm{Ra},{ }^{232} \mathrm{Th}$ and ${ }^{40} \mathrm{~K}$, in the studied muscovite granite. The graphical representations demonstrated that the variation of natural radioactivity levels at the studied area due to the variation of concentrations of radionuclides in the geological rocks. Also indicated that there is some uniformity in the distribution of ${ }^{226} \mathrm{Ra}, 2^{38} \mathrm{U}$, and ${ }^{232} \mathrm{Th}$ nuclei along the studied muscovite granite, but the observed difference was shown for ${ }^{40} \mathrm{~K}$ nuclei.

\subsection{Radon Gas Concentration Using Cup Techniques Employing CR-39 SSNTDs Detectors}

Table 2 shows the measured values for the radon gas concentrations calculated using Equations (1) as well as the track density $\left(\mathrm{T} \cdot \mathrm{cm}^{2} / \mathrm{d}\right)$ counted for each detector. For track density $\left(\mathrm{T} \cdot \mathrm{cm}^{2} / \mathrm{d}\right)$ it ranges from $17.30 \pm 1.68$ to $95.58 \pm 7.43$ with an average value of $50.50 \pm 4.65$, and standard deviation of $23.94 \pm 1.87$, the wide range indicates a large spread in the radon gas concentrations this also was assured by the large values for the standard deviation which is nearly 0.47 from the original results. For radon gas concentration (pci/l), the same behavior can be obtained for the radon concentration which is ranged from $80.34 \pm 7.15$ to $443.94 \pm 31.14$ pci/l with an average value of $234.58 \pm 11.20 \mathrm{pci} / \mathrm{l}$ and standard deviation of $111.20 \pm 8.70$.

The relation between the measured Rn-gas concentration measured by using cup techniques and the measured concentrations for uranium and radium in (ppm) were shown in Figure 6(a) \& Figure 6(b) respectively. From this figure, it is shown that there is a positive correlation namely, 0.618 and 0.797 for uranium and radium, where a great value of radium is expected because the radium is the main cause of radon concentration. The relationship between uranium and radium concentration values in (ppm) was estimated as in Figure 6(c). This relation shows that the obtained correlation factor of is 0.7585 . Hence we can predict a state of some secular equilibrium in these studied samples.

\subsection{Radiological Parameters}

The main and common pathways by which some environmental impacts may be caused are direct external 


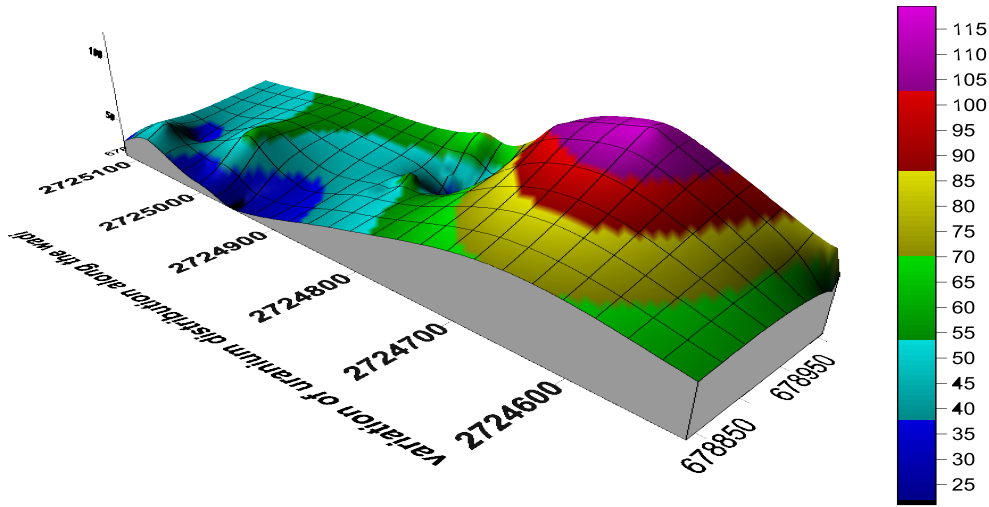

(a)
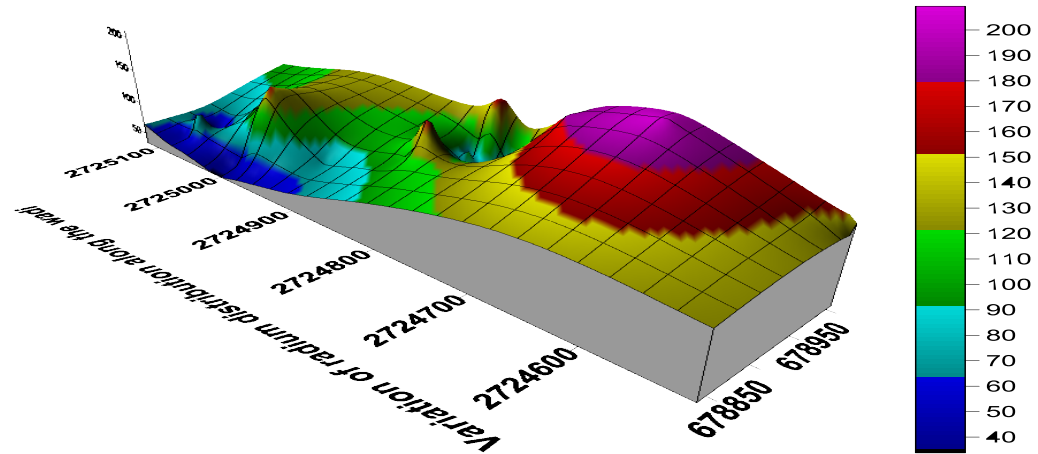

(b)
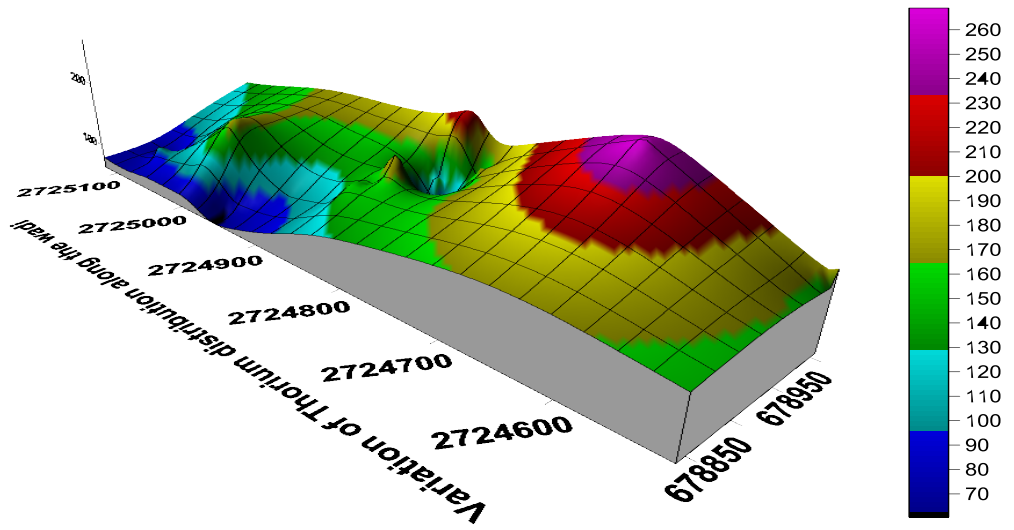

(c)

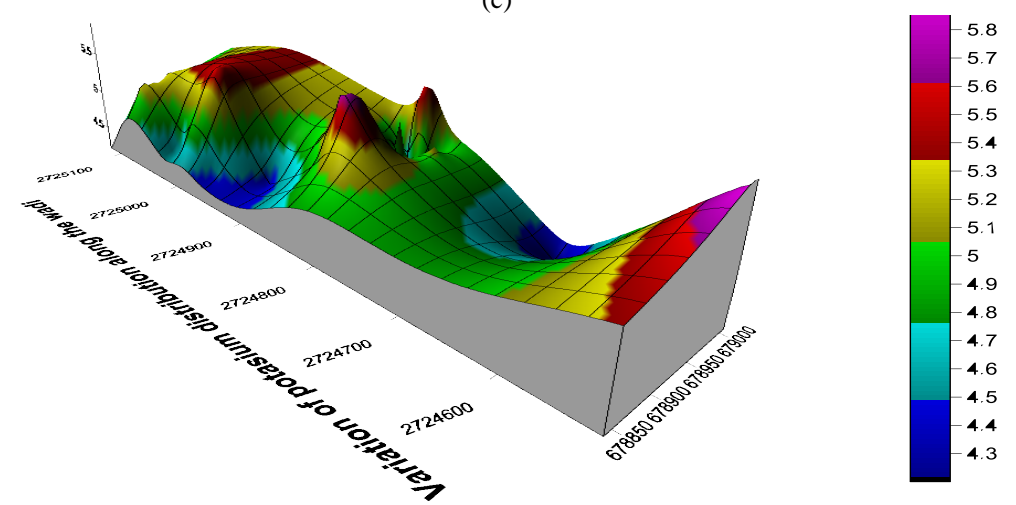

(d)

Figure 5. Graphical diagrams showing the distribution of (a) eU (ppm), (b) eRa (ppm), (c) eTh (ppm) and d) K\% alonge the studied muscovite granite, Wadi Nugrus. 


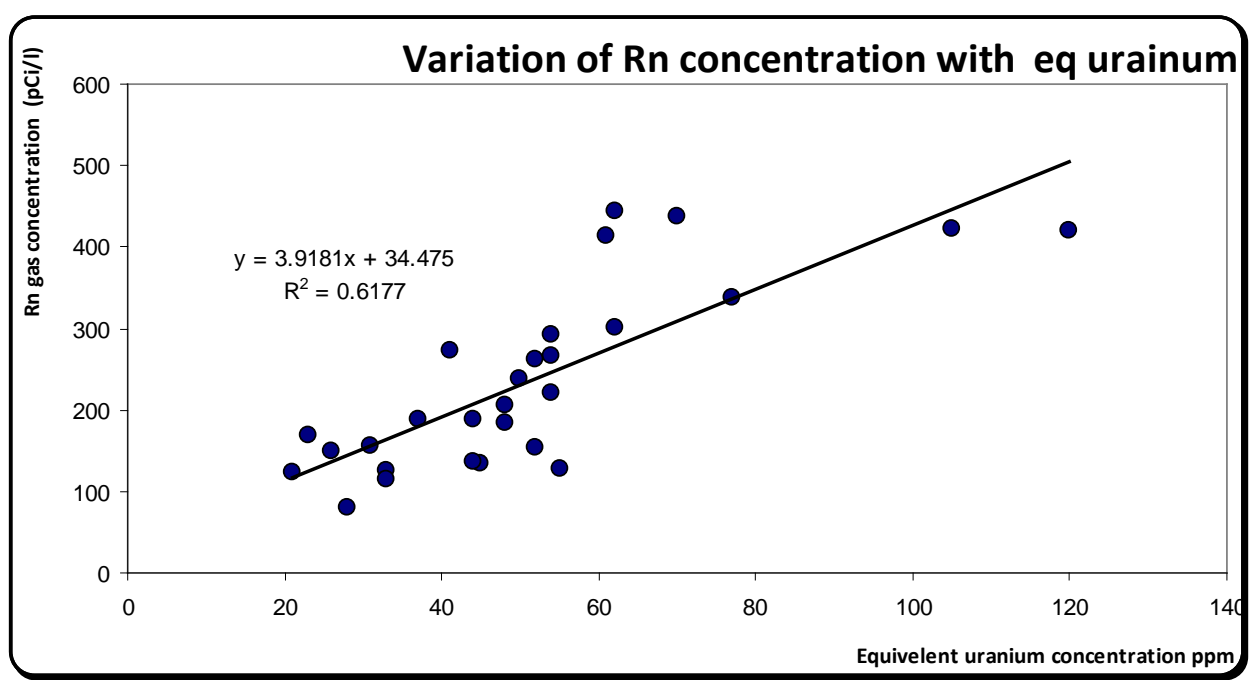

(a)

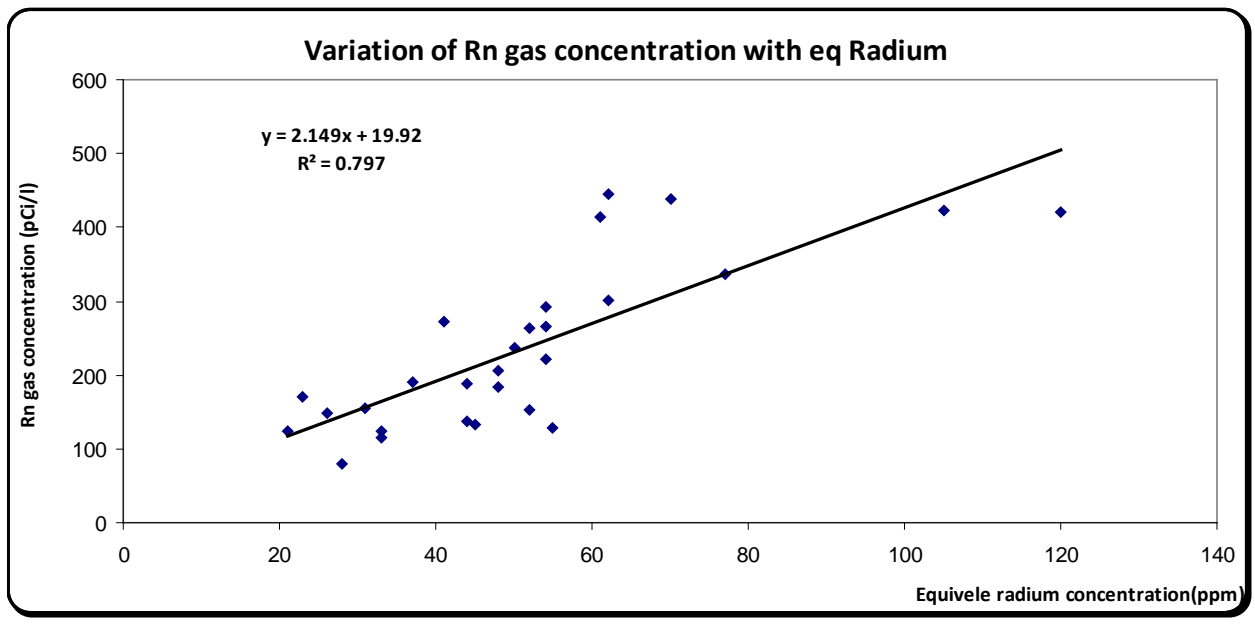

(b)

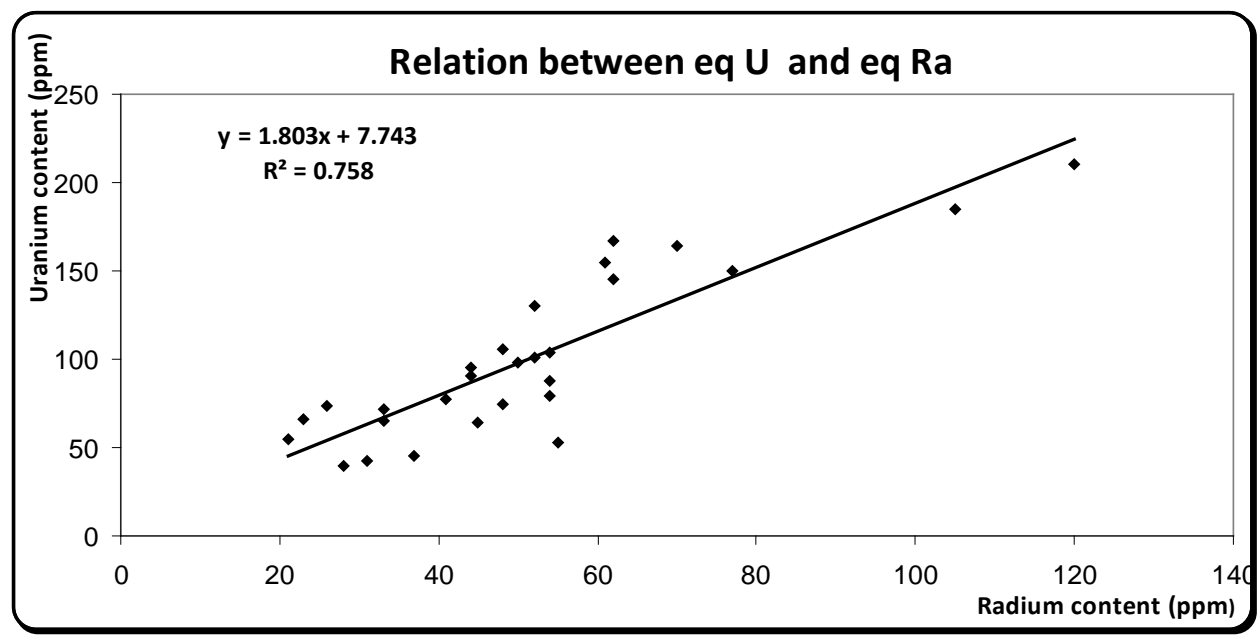

(c)

Figure 6. Binary diagrams showing the correlation between; (a) eU and measured radon gas concentration, (b) eRa and measured radon gas concentration, (c) eU and eRa in the studied muscovite granite, Wadi Nugrus area. 
exposure to radiation, inhalation and ingestion of radioactive materials. This depends on several factors such as radiation type and energy, their total dose, size of irradiation section, the radio sensitivity of the individual and age [27]. Several methods proposed to estimate and discuss the environmental impacts of radiation [14] [28] [29].

\subsubsection{Absorbed Dose Rate}

The absorbed gamma dose rate $\mathrm{D}_{\mathrm{R}}(\mathrm{nGy} / \mathrm{hr})$, in the air at $1 \mathrm{~m}$ above the ground level for the uniform distribution of radionuclides $\left({ }^{226} \mathrm{Ra},{ }^{232} \mathrm{Th}\right.$ and $\left.{ }^{40} \mathrm{~K}\right)$ can be estimated by using the specific activity concentration in $(\mathrm{Bq} / \mathrm{kg})$ from the following equation which is provided by UNSCEAR [14] [30] as;

$$
\mathrm{D}_{\mathrm{R}}(\mathrm{nGy} / \mathrm{h})=0.427 \mathrm{~A}_{\mathrm{Ra}}+0.623 \mathrm{~A}_{\mathrm{Th}}+0.043 \mathrm{~A}_{\mathrm{K}}
$$

where, $A_{R a}, A_{T h}$ and $A_{K}$ are the activity concentration, $\left(\mathrm{Bq} / \mathrm{kg}\right.$ ) for ${ }^{226} \mathrm{Ra},{ }^{232} \mathrm{Th}$ and ${ }^{40} \mathrm{~K}$ respectively. The values 0.427, 0.623 and 0.043 are the conversion factor (nGy/h) per Bq/kg for ${ }^{238} \mathrm{U},{ }^{232} \mathrm{Th}$ and ${ }^{40} \mathrm{~K}$ nuclei respectively. For normal background areas, the average dose rate value is $59 \mathrm{nGy} / \mathrm{h} \mathrm{[14]}$.

The absorbed dose rate (nGy/h) calculated using Equation (2), are ranged from 507.43 to $1846.88 \mathrm{nGy} / \mathrm{h}$ with an average value of $936.36 \pm 383.96 \mathrm{nGy} / \mathrm{h}$, (Table 3) which is about fifteen times higher than the world average value of $59 \mathrm{nGy} \cdot \mathrm{h}^{-1}[14]$.

Table 3. Calculated values for the radiological parameters at the studied area.

\begin{tabular}{|c|c|c|c|c|c|c|c|}
\hline S. No. & $\mathrm{D}_{\mathrm{R}}(\mathrm{nG} \mathbf{y} / \mathbf{h})$ & $(\text { AEDR })_{\text {intdoor }}\left(\mathrm{mSv} \cdot \mathrm{y}^{-1}\right)$ & $(\mathrm{AEDR})_{\text {outdoor }}\left(\mathrm{mSv} \cdot \mathrm{y}^{-1}\right)$ & $\mathbf{R}_{\mathrm{eq}}$ & $\mathbf{H}_{\text {in }}$ & $\mathbf{H}_{\mathrm{ex}}$ & $\mathbf{I}-\boldsymbol{\gamma}_{\mathrm{r}}$ \\
\hline 1t & 596.59 & 0.525 & 2.099 & 1356.83 & 5.84 & 3.67 & 9.39 \\
\hline 2 & 551.83 & 0.689 & 2.758 & 1244.34 & 5.13 & 3.36 & 8.70 \\
\hline 3 & 587.77 & 0.598 & 2.392 & 1334.29 & 5.74 & 3.60 & 9.25 \\
\hline $4 t$ & 468.10 & 0.496 & 1.986 & 1048.95 & 4.17 & 2.83 & 7.38 \\
\hline 5 & 842.79 & 0.704 & 2.815 & 1923.19 & 8.37 & 5.20 & 13.27 \\
\hline 6 & 517.28 & 0.563 & 2.253 & 1167.09 & 4.55 & 3.15 & 8.17 \\
\hline 7 & 586.54 & 0.667 & 2.670 & 1324.09 & 5.08 & 3.58 & 9.27 \\
\hline $8 t$ & 1345.51 & 1.042 & 4.168 & 3088.45 & 13.52 & 8.34 & 21.20 \\
\hline $9 t$ & 507.43 & 0.402 & 1.609 & 1147.66 & 4.94 & 3.10 & 7.98 \\
\hline 10 & 689.32 & 0.593 & 2.372 & 1570.02 & 6.64 & 4.24 & 10.87 \\
\hline $11 t$ & 982.17 & 0.887 & 3.550 & 2242.56 & 9.43 & 6.06 & 15.49 \\
\hline 12 & 837.90 & 0.723 & 2.894 & 1913.01 & 8.21 & 5.17 & 13.20 \\
\hline $13 t$ & 980.02 & 0.891 & 3.565 & 2238.92 & 9.32 & 6.05 & 15.47 \\
\hline $14 t$ & 1001.28 & 0.853 & 3.411 & 2284.92 & 9.71 & 6.17 & 15.78 \\
\hline $15 t$ & 1453.14 & 1.103 & 4.412 & 3337.76 & 14.59 & 9.02 & 22.90 \\
\hline 16 & 663.76 & 0.503 & 2.014 & 1507.08 & 6.54 & 4.07 & 10.45 \\
\hline $17 t$ & 587.02 & 0.442 & 1.767 & 1332.37 & 5.80 & 3.60 & 9.24 \\
\hline $18 t$ & 995.47 & 0.897 & 3.589 & 2273.80 & 9.61 & 6.14 & 15.70 \\
\hline 19 & 733.23 & 0.666 & 2.665 & 1673.39 & 7.09 & 4.52 & 11.56 \\
\hline $20 t$ & 910.88 & 0.955 & 3.821 & 2080.29 & 8.26 & 5.62 & 14.41 \\
\hline 21 & 1490.44 & 1.220 & 4.879 & 3422.63 & 14.72 & 9.25 & 23.50 \\
\hline $22 t$ & 780.00 & 0.782 & 3.127 & 1776.86 & 7.30 & 4.80 & 12.31 \\
\hline 23 & 950.05 & 0.945 & 3.781 & 2167.67 & 8.79 & 5.86 & 15.01 \\
\hline 24 & 1563.77 & 1.400 & 5.601 & 3602.24 & 15.91 & 9.73 & 24.64 \\
\hline $25 t$ & 1846.88 & 1.682 & 6.731 & 4262.29 & 18.52 & 11.52 & 29.13 \\
\hline 26 & 1157.01 & 0.914 & 3.658 & 2647.59 & 11.49 & 7.15 & 18.23 \\
\hline $27 t$ & 1290.46 & 1.045 & 4.183 & 2968.46 & 12.86 & 8.02 & 20.35 \\
\hline 28 & 1301.44 & 1.124 & 4.495 & 2986.06 & 13.07 & 8.07 & 20.50 \\
\hline Avg. & 936.36 & 0.833 & 3.331 & 2140.10 & 9.11 & 5.78 & 14.76 \\
\hline Stdv. & 383.96 & 0.300 & 1.201 & 861.16 & 3.86 & 2.33 & 5.84 \\
\hline
\end{tabular}


The fractional contributions of the radionuclides $\left({ }^{226} \mathrm{Ra},{ }^{232} \mathrm{Th}\right.$ and $\left.{ }^{40} \mathrm{~K}\right)$ to the total absorbed dose rate were listed in Table 3 for the ${ }^{226} \mathrm{Ra}$ it ranges from 0.40 to 0.62 with average value of 0.55 for ${ }^{232} \mathrm{Th}$ it ranges from 0.30 to 0.48 with average value of 0.37 while for ${ }^{40} \mathrm{~K}$ it ranges from 0.031 to 0.15 with average value of 0.081 from these data we can conclude that the relative contributions due to ${ }^{226} \mathrm{Ra}$, was $55 \%$ followed by contributions due to ${ }^{232} \mathrm{Th}$ and ${ }^{40} \mathrm{~K}$ as $36.9 \%$ and $8.1 \%$ respectively this means that the potassium contributes by a very small values in the total absorbed dose rate. These data are contradicts with that obtained by EL-Taher and Al Zahrani [31], for the contributions of ${ }^{226} \mathrm{Ra},{ }^{232} \mathrm{Th}$ and ${ }^{40} \mathrm{~K}$ in Saudi Arabia soils.

\subsubsection{Annual Effective Dose Equivalent}

To estimate annual effective dose rate, account must be taken of (a) the conversion coefficient from absorbed dose in air to effective dose and (b) the outdoor occupancy factor. The average numerical values of those parameters vary with the age of the population and the climate at the location considered. According to UNSCEAR [14] [30], the committee used $0.7 \mathrm{~Sv} \cdot \mathrm{Gy} / \mathrm{y}$ for the conversion coefficient from absorbed dose rate in air to effective dose received by adults and 0.2 for the outdoors occupancy factor, 0.8 for indoor, the components of the annual effective dose rate (AEDE) are determined as follows (qoseem).

$$
(\text { AEDE })_{\text {outdoor }}\left(\mathrm{mSv} \cdot \mathrm{y}^{-1}\right)=\mathrm{D}_{\mathrm{R}}(\mathrm{nGy} / \mathrm{h}) * 8760\left(\mathrm{~h} \cdot \mathrm{y}^{-1}\right) * 0.2 * 0.7 *\left(10^{3} \mathrm{mSv} / \mathrm{nGy} 10^{9}\right)
$$

And it can be simplified into (AEDR) $)_{\text {outdoor }}=\mathrm{D}_{\mathrm{R}} * 1.226 * 10^{-3}(\mathrm{mSv} / \mathrm{y})$

$$
\begin{aligned}
& (\mathrm{AEDE})_{\text {indoor }}\left(\mathrm{mSv} \cdot \mathrm{y}^{-1}\right)=\mathrm{D}_{\mathrm{R}}(\mathrm{nGy} / \mathrm{h}) * 8760\left(\mathrm{~h} \cdot \mathrm{y}^{-1}\right) * 0.8 * 0.7 *\left(10^{3} \mathrm{mSv} / \mathrm{nGy} 10^{9}\right) \\
& \text { And it can be simplified into }(\mathrm{AEDR})_{\text {indoor }}=\mathrm{D}_{\mathrm{R}} * 4.905 * 10^{-3}(\mathrm{mSv} / \mathrm{y})
\end{aligned}
$$

where, $\mathrm{mSv} \cdot \mathrm{y}^{-1}$ is the effective dose rate, $(\mathrm{nGy} / \mathrm{h})$ is the dose rate and $0.7 \mathrm{~Sv} \cdot \mathrm{Gy}^{-1}$., is the conversion factor., the average numerical values are vary with age of the population and the climate at the location considered. The resulting world average of the annual effective dose is $0.48 \mathrm{mSv}$ [14].

The obtained values for the outdoor annual effective dose rates $\left(\mathrm{mSv} \cdot \mathrm{y}^{-1}\right)$, which calculated using Equation (3) are ranged from 1.609 to $6.731 \mathrm{mSv} \cdot \mathrm{y}^{-1}$ with an average value $3.331 \pm 1.201 \mathrm{mSv} \cdot \mathrm{y}^{-1}$, The corresponding world average value is $0.41 \mathrm{mSv} \cdot \mathrm{y}^{-1}$ of which $0.07 \mathrm{mSv} \cdot \mathrm{y}^{-1}$ is from outdoor and $0.34 \mathrm{mSv} \cdot \mathrm{y}^{-1}$ from indoor exposure [32]. There for the study area is out of normal values and has a great threat to the environment as well as human health.

The obtained values for the indoor annual effective dose equivalent $\left(\mathrm{mSv} \cdot \mathrm{y}^{-1}\right)$, which calculated using Equation (4) are ranged from 0.402 to $1.682 \mathrm{mSv} \cdot \mathrm{y}^{-1}$ with an average value $0.833 \pm 0.300 \mathrm{mSv} \cdot \mathrm{y}^{-1}$ (Table 3), where the $\left(1 \mathrm{mSv} \cdot \mathrm{y}^{-1}\right)$ is the annual effective dose rate limit for the public exposure (ICRP, 2000). The resulting worldwide average of the annual dose is $0.48 \mathrm{mSv}$, with the results for individual countries being generally within the 0.3 - 0.6 mSv, range [14].

\subsubsection{Radium Equivalent Activity ( $R_{\text {eq }}$ )}

$\mathrm{R}_{\mathrm{eq}}$ is the weighted sum of activities of the three radionuclides ${ }^{226} \mathrm{Ra}$, ${ }^{232} \mathrm{Th}$ and ${ }^{40} \mathrm{~K}$ based on the estimation that $370 \mathrm{~Bq} \cdot \mathrm{kg}^{-1}$ of ${ }^{226} \mathrm{Ra}, 259 \mathrm{~Bq} \cdot \mathrm{kg}^{-1}$ of ${ }^{232} \mathrm{Th}$ and $4810 \mathrm{~Bq} \cdot \mathrm{kg}^{-1}$ of ${ }^{40} \mathrm{~K}$ produce the same gamma-ray dose rate [33], its mathematically defined by UNSCEAR [14] as:

$$
\mathrm{Ra}_{\mathrm{eq}}(\mathrm{Bq} / \mathrm{kg})=\mathrm{A}_{\mathrm{Ra}}+1.43 \mathrm{~A}_{\mathrm{Th}}+0.077 \mathrm{~A}_{\mathrm{K}} \leq 370
$$

where, $A_{U}, A_{T h}$ and $A_{K}$ are the specific activities of $U$, Th, and $K$ respectively. By assuming that $10 \mathrm{~Bq} / \mathrm{kg}$ of ${ }^{238} \mathrm{Ra}$ equal $7 \mathrm{~Bq} / \mathrm{kg}$ of ${ }^{232} \mathrm{Th}$ and $130 \mathrm{~Bq} / \mathrm{kg}$ of ${ }^{40} \mathrm{~K}$ produced equal gamma dose rate [34] [35]. The maximum value of $\mathrm{Ra}_{\mathrm{eq}}$ must be less than $370 \mathrm{~Bq} / \mathrm{kg}$, which equivalent to the annual dose rate of $1 \mathrm{mSv} / \mathrm{y}$, and meeting the maximum permissible dose to human from their exposure to natural radiation from soil in one year.

The obtained values of the $R_{a}$ that calculated using Equation (5) are ranged from 1048.95 to $4262.29 \mathrm{~Bq} \cdot \mathrm{kg}^{-1}$ with an average value $2140.1 \pm 861.16 \mathrm{~Bq} \cdot \mathrm{kg}^{-1}$ (Table 3 ). The calculated values are very greater than the recommended value.

\subsubsection{External Hazard Index (Hex)}

Radiation exposure due to ${ }^{226} \mathrm{Ra},{ }^{232} \mathrm{Th}$ and ${ }^{40} \mathrm{~K}$ may be external or internal. The external hazard index or outdoor radiation hazard index $\left(\mathrm{H}_{\mathrm{ex}}\right)$ was used to measure the external hazard due to the emitted gamma radiation and it can be calculated using the following equation [36]. 


$$
\mathrm{H}_{\mathrm{ex}}=\frac{\mathrm{A}_{\mathrm{Ra}}}{370}+\frac{\mathrm{A}_{\mathrm{Th}}}{259}+\frac{\mathrm{A}_{\mathrm{K}}}{4810} \leq 1
$$

where, $H_{e x}$ is the external hazard index, $A_{R a}, A_{\text {Th }}$ and $A_{K}$ are activity concentrations of ${ }^{226} \mathrm{Ra},{ }^{232} \mathrm{Th}$ and ${ }^{40} \mathrm{~K}$, respectively in $\mathrm{Bq} \cdot \mathrm{kg}^{-1}$.

The values of the hazard index must be less than the unity in order to keep the radiation (external) hazard (which is caused by gamma rays) to be insignificant unity corresponds to the upper limit of radiation (radium) equivalent activity $(370 \mathrm{~Bq} / \mathrm{kg})$.

\subsubsection{Internal Hazard Index $\left(\mathrm{H}_{\text {in }}\right)$}

In addition to external hazard index, radon and its short-lived products (isotopes) are also hazardous to the respiratory organs. So, the internal to radon and its daughter products is quantified by the internal hazard index $\left(\mathrm{H}_{\text {in }}\right)$ which controls the internal exposure to ${ }^{222} \mathrm{Rn}$ and its radioactive progeny [37] [38] as:

$$
\mathrm{H}_{\text {in }}=\frac{\mathrm{A}_{\mathrm{Ra}}}{185}+\frac{\mathrm{A}_{\mathrm{Th}}}{259}+\frac{\mathrm{A}_{\mathrm{K}}}{4810} \leq 1
$$

where $H_{\text {in }}$ is internal hazard index and $A_{R a}$, $A_{T h}$ and $A_{K}$ are activity concentrations of ${ }^{226} \mathrm{Ra}$, ${ }^{232} \mathrm{Th}$ and ${ }^{40} \mathrm{~K}$, respectively, in $\mathrm{Bq} \cdot \mathrm{kg}^{-1}$.

The value of this index should be less than unity in order for the radiation hazard to have negligible hazardous effects to the respiratory organs of the public [35]. The value of the external and internal hazard index calculated using Equations (6 \& 7) was represented in Table 3, which shows that, for the external hazard index $\left(\mathrm{H}_{\mathrm{ex}}\right)$ the averages from all the studied samples were ranged from 2.83 to 11.52 with an average value of $5.78 \pm 2.33$, this average value is greater than the acceptable average value of unity [39], which means that the external hazard due to gamma emission is very serious, while, for the internal hazard index $\left(\mathrm{H}_{\mathrm{in}}\right)$ the averages values from all studied samples were ranged from 4.17 to 18.52 with an average value of $9.11 \pm 3.86$, which is a very great values compared with the acceptable values, unity, this means that radon an its radioactive progeny plays a significant role in the expected internal hazard due to radiation in the studied area.

\subsubsection{Representative Level Index (I $\left.\gamma_{\mathrm{r}}\right)$}

The radioactivity level index is used to estimate the level of radiation risk, especially $\gamma$-rays, associated with natural radionuclides in specific materials. It is defined by NEA-OECD and Alam [40] [41] as;

$$
I \gamma_{\mathrm{r}}=\left(\frac{\mathrm{A}_{\mathrm{Ra}}}{150 \mathrm{Bp} / \mathrm{kg}}+\frac{\mathrm{A}_{\mathrm{Th}}}{100 \mathrm{Bp} / \mathrm{kg}}+\frac{\mathrm{A}_{\mathrm{K}}}{1500 \mathrm{Bp} / \mathrm{kg}}\right)
$$

where, $A_{R a}, A_{T h}$ and $A_{K}$ are the Activity concentrations of ${ }^{226} \mathrm{Ra},{ }^{232} \mathrm{Th}$ and ${ }^{40} \mathrm{~K}$ in $\mathrm{Bq} / \mathrm{kg}$ respectively. The safety value for this index is $\leq 1$.

Table 3 shows the obtained results for $\left(\mathrm{I}-\gamma_{\mathrm{r}}\right)$ that calculated using Equation (8). The obtained values are ranged from 7.38 to 29.13 with an average value of $14 \pm 5.84$, which is a very far from the acceptable values indicating a very high radiation risk in the study area.

The fractional contributions of the radionuclides $\left({ }^{226} \mathrm{Ra},{ }^{232} \mathrm{Th}\right.$ and $\left.{ }^{40} \mathrm{~K}\right)$ to the internal and external hazard indices factor were listed in Table 4. In case of internal hazard index $\left(\mathrm{H}_{\text {in }}\right)$ : For the ${ }^{226} \mathrm{Ra}$ it ranges from 0.59 to 0.78 with average value of 0.72 for ${ }^{232} \mathrm{Th}$ it ranges from 0.19 to 0.35 with average value of 0.24 while for ${ }^{40} \mathrm{~K}$ it ranges from 0.015 to 0.081 with average value of 0.041 from these data we can conclude that the relative contributions due to ${ }^{226} \mathrm{Ra}$, was $72 \%$ followed by contributions due to ${ }^{232} \mathrm{Th}$ and ${ }^{40} \mathrm{~K}$ as $24 \%$ and $4.1 \%$.

In case of external hazard index $\left(\mathrm{H}_{\mathrm{ex}}\right)$ : For the ${ }^{226} \mathrm{Ra}$, it ranges from 0.42 to 0.63 with average value of 0.57 for ${ }^{232} \mathrm{Th}$ it ranges from 0.30 to 0.49 with average value of 0.37 while for ${ }^{40} \mathrm{~K}$ it ranges from 0.024 to 0.119 with average value of 0.064 from these data we can conclude that the relative contributions due to ${ }^{226} \mathrm{Ra}$, was $57 \%$ followed by contributions due to ${ }^{232} \mathrm{Th}$ and ${ }^{40} \mathrm{~K}$ as $37 \%$ and $6 \%$ respectively.

\section{Discussion and Conclusion}

The muscovite granite of Wadi Nugrus has an irregular shape being emplaced into the biotite schists which undergo high temperature-low pressure metamorphism [42] [43]. 
Table 4. The fractional contributions of the natural radioactive nuclides in the total absorbed dose rate as well as internal and external radiation indices at the studied area.

\begin{tabular}{|c|c|c|c|c|c|c|c|c|c|}
\hline \multirow{2}{*}{ S. No. } & \multicolumn{3}{|c|}{$\mathbf{H}_{\text {in }}$} & \multicolumn{3}{|c|}{$\mathbf{H}_{\mathrm{ex}}$} & \multicolumn{3}{|c|}{ Absorbed Dose Rate (nGy/h) } \\
\hline & eRa & eTh & $\mathbf{K}$ & eRa & eTh & $\mathbf{K}$ & eRa & eTh & $\mathbf{K}$ \\
\hline 1t & 0.74 & 0.21 & 0.047 & 0.59 & 0.33 & 0.075 & 0.57 & 0.33 & 0.095 \\
\hline 2 & 0.69 & 0.24 & 0.066 & 0.53 & 0.37 & 0.101 & 0.51 & 0.37 & 0.127 \\
\hline 3 & 0.74 & 0.20 & 0.051 & 0.59 & 0.33 & 0.081 & 0.57 & 0.32 & 0.103 \\
\hline $4 t$ & 0.64 & 0.28 & 0.081 & 0.47 & 0.41 & 0.119 & 0.45 & 0.40 & 0.150 \\
\hline 5 & 0.76 & 0.20 & 0.040 & 0.61 & 0.33 & 0.064 & 0.59 & 0.32 & 0.081 \\
\hline 6 & 0.62 & 0.32 & 0.064 & 0.44 & 0.46 & 0.093 & 0.43 & 0.45 & 0.117 \\
\hline 7 & 0.59 & 0.35 & 0.063 & 0.42 & 0.49 & 0.089 & 0.40 & 0.48 & 0.112 \\
\hline $8 t$ & 0.77 & 0.21 & 0.027 & 0.62 & 0.34 & 0.044 & 0.61 & 0.34 & 0.056 \\
\hline $9 t$ & 0.74 & 0.20 & 0.059 & 0.59 & 0.31 & 0.094 & 0.57 & 0.31 & 0.119 \\
\hline 10 & 0.72 & 0.23 & 0.043 & 0.57 & 0.37 & 0.068 & 0.55 & 0.36 & 0.086 \\
\hline $11 t$ & 0.72 & 0.25 & 0.037 & 0.56 & 0.39 & 0.058 & 0.54 & 0.38 & 0.074 \\
\hline 12 & 0.74 & 0.22 & 0.038 & 0.59 & 0.35 & 0.060 & 0.57 & 0.35 & 0.077 \\
\hline $13 t$ & 0.70 & 0.26 & 0.036 & 0.54 & 0.40 & 0.055 & 0.53 & 0.40 & 0.070 \\
\hline $14 t$ & 0.73 & 0.23 & 0.039 & 0.57 & 0.37 & 0.061 & 0.56 & 0.36 & 0.078 \\
\hline $15 t$ & 0.76 & 0.21 & 0.025 & 0.62 & 0.34 & 0.041 & 0.61 & 0.34 & 0.053 \\
\hline 16 & 0.76 & 0.19 & 0.051 & 0.61 & 0.31 & 0.082 & 0.59 & 0.31 & 0.103 \\
\hline $17 t$ & 0.76 & 0.19 & 0.052 & 0.61 & 0.30 & 0.083 & 0.59 & 0.30 & 0.105 \\
\hline $18 t$ & 0.72 & 0.24 & 0.037 & 0.57 & 0.38 & 0.057 & 0.55 & 0.38 & 0.073 \\
\hline 19 & 0.72 & 0.24 & 0.039 & 0.57 & 0.37 & 0.060 & 0.55 & 0.37 & 0.077 \\
\hline $20 t$ & 0.64 & 0.33 & 0.035 & 0.47 & 0.48 & 0.051 & 0.46 & 0.48 & 0.065 \\
\hline 21 & 0.74 & 0.23 & 0.025 & 0.59 & 0.37 & 0.040 & 0.58 & 0.37 & 0.051 \\
\hline $22 t$ & 0.69 & 0.27 & 0.042 & 0.52 & 0.41 & 0.064 & 0.51 & 0.41 & 0.081 \\
\hline 23 & 0.67 & 0.29 & 0.038 & 0.50 & 0.44 & 0.057 & 0.49 & 0.44 & 0.072 \\
\hline 24 & 0.78 & 0.20 & 0.020 & 0.63 & 0.33 & 0.032 & 0.62 & 0.33 & 0.041 \\
\hline $25 t$ & 0.76 & 0.23 & 0.015 & 0.61 & 0.37 & 0.024 & 0.60 & 0.37 & 0.031 \\
\hline 26 & 0.76 & 0.21 & 0.033 & 0.61 & 0.34 & 0.054 & 0.59 & 0.34 & 0.069 \\
\hline $27 t$ & 0.75 & 0.23 & 0.022 & 0.60 & 0.36 & 0.035 & 0.59 & 0.36 & 0.045 \\
\hline 28 & 0.77 & 0.21 & 0.028 & 0.62 & 0.33 & 0.045 & 0.61 & 0.33 & 0.058 \\
\hline Avg. & 0.72 & 0.24 & 0.041 & 0.57 & 0.37 & 0.064 & 0.550 & 0.369 & 0.081 \\
\hline
\end{tabular}

In addition to quartz, perthitic K-feldspar, and albite, the muscovite granite consists of variable contents of muscovite, garnet, biotite, and accessory as allanite, zircon, and fluorite.

Melting of crustal material of variable compositions to produce granitic melts of orogenic and of anorogenic characters has been documented for a number of granitic complexes [44]-[48]. The highly evolved nature of the studied muscovite granite, it's exclusively peraluminous character, with mineral phases containing A/CNK > 1 [18] [19]. Mineralogically, the studied muscovite granite has important minerals as: uranophane, autunite, ura- 
nothorite, columbite, metamict zircon, fluorite, zinnwaldite and hematite.

The studied muscovite granite of Wadi Nugrus shows that $U_{c h} / e U$ is more unity and the measured $U_{c h}$ is higher than the measured eU in the most analyzed samples specially taken from trenches, which reflects disequilibrium due to the addition of uranium minerals.

The contributions of the three nuclei in the total absorbed dose rates and internal and external hazardous, for ${ }^{226} \mathrm{Ra}$, it contributes by $72 \%$ in $\mathrm{H}_{\text {in }}, 57 \%$ in $\mathrm{H}_{\text {ex }}$ and $55 \%$ of $\mathrm{D}_{\mathrm{R}}$, for ${ }^{232} \mathrm{Th}$ it contributes by $24 \%$ in $\mathrm{H}_{\text {in }}, 37 \%$ in $\mathrm{H}_{\text {ex }}$ and $36.9 \%$ of $\mathrm{D}_{\mathrm{R}}$, while for ${ }^{40} \mathrm{~K}$ it contributes by $4.1 \%$ in $\mathrm{H}_{\text {in }}, 6.4 \%$ in $\mathrm{H}_{\text {ex }}$ and $8.1 \%$ of $\mathrm{D}_{\mathrm{R}}$.

For the studied area, the most important nuclide is ${ }^{226} \mathrm{Ra}$ which comes as a daughter nuclide of ${ }^{238} \mathrm{U}$ and insures by the great concentrations of radon gas measured by cup technique in the study area. These results can also be treated as there is addition of uranium from outer sources as mentioned in Table 1. The above mentioned results are contradicts with that obtained by EL-Taher and AL-Zaharni [31], which states that the contributions of ${ }^{40} \mathrm{~K}$ is $65.6 \%$, ${ }^{226} \mathrm{Ra} 11.26 \%$ and ${ }^{232} \mathrm{Th} 23.14 \%$ in soils of AL-Quassim region, Saudi Arabia. From the other side, increasing of contribution of radium reflects the more additions of recent uranium are took place which are supported by geological, mineralogical and geochemical studies.

For the measurements done by Refaat, [49] in metamorphosed sandstone, at Wadi Sikait area, he found that the contributions of the three nuclei in the total absorbed dose rates and internal and external hazardous, for ${ }^{226} \mathrm{Ra}$, it contributed by $53.76 \%$ in $\mathrm{H}_{\mathrm{in}}, 38.66 \%$ in $\mathrm{H}_{\text {ex }}$ and 41.98 of $\mathrm{D}_{\mathrm{R}}$, for ${ }^{232} \mathrm{Th}$ it contributed by $27.63 \%$ in $\mathrm{H}_{\text {in }}$, $35.74 \%$ in $\mathrm{H}_{\mathrm{ex}}$ and $29.74 \%$ of $\mathrm{D}_{\mathrm{R}}$, while for ${ }^{40} \mathrm{~K}$ it contributed by $17.75 \%$ in $\mathrm{H}_{\mathrm{in}}, 25.63 \%$ in $\mathrm{H}_{\mathrm{ex}}$ and $28.27 \%$ of $\mathrm{D}_{\mathrm{R}}$. These results included that the contributions of ${ }^{40} \mathrm{~K}$ were nearly three times greater than that obtained by this study that might be due to K-feldspar which were dominant. The contributions of ${ }^{226} \mathrm{Ra}$ are in general less that obtained in this study; this means that the radioactivity in Wadi Sikait area is due to recent uranium.

A greet take care must be taken in account when dealing with the studied area, the precautions of radiation protection procedures should be taken in consideration. The samples collected from these areas are not safe and cannot used as a construction material because it possesses a great radiological threat to population and great care when handling is required.

\section{Acknowledgements}

The authors would like to express their wishes to deep thank for Prof. Dr. Gehad M. Saleh for helping and supporting this work. Deep thanks for Prof. Dr. Hamed A. Mira, for his help and reviewing the manuscript.

\section{References}

[1] Greiling, R.O., Kr“oner, A., El-Ramly, M.F. and Rashwan, A.A. (1988) Structural Relations between the Southern and Central Parts of the Eastern Desert of Egypt: Details of an Fold and Thrusts Belt. In: El-Gaby, S. and Greiling, R., Eds., The Pan-African Belt of the NE Africa and Adjacent Areas, Tectonic Evolution and Economic Aspects, Freidr. Vieweg \& Sohn, Braunschweig/Weisbaden, 121-145.

[2] Fritz, H., Wallbrecher, E., Khudeir, A.A., Abu El-Ela, F.F. and Dallmeyer, D.R. (1996) Formation of Neoproterozoic Metamorphic Core Complexes during Oblique Convergence Eastern Desert, Egypt. Journal of African Earth Sciences, 23, 311-329. http://dx.doi.org/10.1016/S0899-5362(97)00004-3

[3] Fowler, A. and Osman, A.F. (2009) The Sha'it-Nugrus Shear Zone Separating Central and South Eastern Deserts, Egypt: A Post-Arc Collision Low-Angle Normal Ductile Shear Zone. Journal of African Earth Sciences, 53, 16-32. http://dx.doi.org/10.1016/j.jafrearsci.2008.07.006

[4] El Bayoumi, R.M. (1980) Ophiolites and Associated Rocks of the Wadi Ghadir, East of Gebel Zabara. Eastern Desert, Egypt. PhD Thesis, Cairo Univ., Egypt, 227 p.

[5] Hume, W.F. (1935) Geology of Egypt. Vol. II, Part II. The Later Plutonic and Intrusive Rocks. Geol. Surv. Egypt. Government Press, Cairo, 301-688.

[6] El Gaby, S. (1975) Petrochemistry and Geochemistry of Some Granite from Egypt. Neues Jahrbuch für Mineralogie Abhandlungen, 124, 147-189.

[7] Hussien, A.A., Ali, M.M. and El Rally, M.F. (1982) A Proposed New Classification of the Granites of Egypt. Journal of Volcanology and Geothermal Research, 14, 187-198. http://dx.doi.org/10.1016/0377-0273(82)90048-8

[8] Benard, B. (1996) Genesis of the Two Main Types of Peraluminous Granitoids. Geology, 24, 295-298. http://dx.doi.org/10.1130/0091-7613(1996)024<0295:GOTTMT>2.3.CO;2

[9] Fares, S., Ali, A.M., Yassene, A., Ashour, M.K., Abu-Assy, M. and El-Rahman, A. (2011) Natural Radioactivity and 
the Resulting Radiation Doses in Some Kinds of Commercially Marble Collected from Different Quarries and Factories in Egypt. 3, 895-905. http://dx.doi.org/10.4236/ns.2011.310115

[10] Khan, K., Khan, H.M., Tufail, M. and Ahmed, N. (1998) Radiometric Analysis of Hazara Phosphate Rock and Fertilizers. Journal of Environmental Radioactivity, 38, 77-83. http://dx.doi.org/10.1016/S0265-931X(97)00018-0

[11] Menon, M.R., Mishra, U.C., Lalit, B.Y., Shukla, V.K. and Ramachandran, T.V. (1982) Uranium Thorium and Potassium in Indian Rocks and Ores. Proceedings of the Indian Academy of Sciences (Earth and Planetary Sciences), 91, 127-136.

[12] Turhan, S. and Gunduz, L. (2008) Determination of Specific Activity of ${ }^{226} \mathrm{Ra},{ }^{232} \mathrm{Th}$ and ${ }^{40} \mathrm{~K}$ for Assessment of Radiation Hazards from Turkish Pumice Samples. Journal of Environmental Radioactivity, 99, 332-342. http://dx.doi.org/10.1016/j.jenvrad.2007.08.022

[13] Khan, H.M., Khan, K., Atta, M.A. and Jan, F. (1994) Measurement of Gamma Activity of Soil Samples of Charsadda District of Pakistan. Journal of the Chemical Society of Pakistan, 16, 183-188.

[14] UNSCEAR (2000) Sources and Effects of Ionizing Radiation. UNSCEAR Report on the General Assembly with Scientific Annexes, Vol. 1, Sources.

[15] Sabharwal, A.D., Singh, B., Kumar, S. and Singh, S. (2012) Natural Radioactivity Levels (K, Th and Ra) in Some Areas of Punjab, India EPJ Web of Conferences 24 05010(2012) Assembly, with Scientific Annexes. United Nations, New York.

[16] Kinyua, R., Atambo, V.O. and Ongeri, R.M. (2011) Activity Concentrations of ${ }^{40} \mathrm{~K},{ }^{232} \mathrm{Th},{ }^{226}$ Ra and Radiation Exposure Levels in the Tabaka Soapstone Quarries of the Kisii Region, Kenya. African Journal of Environmental Science and Technology, 5, 682-688.

[17] Ibrahim, M.E., Saleh, G.M., Abdallah, S.A., Nezar, A.D. and Mahmoud, M.A.M. (2011) Geology and Geochemistry of Wadi Nugrus Leucogranite, South Eastern Desert, Egypt. Bulletin of the Faculty of Science.

[18] Saleh, G.M. (2014) Geology of Wadi El Gemal-Wadi Nugrus Area, South Eastern Desert, Egypt. in press.

[19] Saker, R.M. (2015) Geochemistry and Uranium Potentiality of Wadi Nugrus-Wadi El Nom Area, Southeastern Desert, Egypt. MSc Thesis, El Menoufiya Univ., 197 p.

[20] Matolin, M. (1991) Construction and Use of Spectrometric Calibration Pads Laboratory $\gamma$-Ray Spectrometry, NMA, Egypt. A Report to the Government of the Arab Republic of Egypt, Project EGY/4/030-03, IAEA.

[21] Hamby, D.M. and Tynybekov, A.K. (2000) Uranium, Thorium and Potassium in Soils along the Shore of Lake IssykKyol in the Kyrghyz Republic. Environmental Monitoring and Assessment, 73, 101-108. http://dx.doi.org/10.1023/A:1013071414970

[22] Al-Jundi, J. (2002) Population Doses from Terrestrial Gamma Exposure in Areas near to Old Phosphate Mine, Russaifa, Jordan. Radiation Measurements, 35, 23-28. http://dx.doi.org/10.1016/S1350-4487(01)00261-X

[23] IAEA (1989) Radiation Safty and Protection in the Field of Radioactive Ores Prospecyion, Exploration and Minging. Project: EGY/9/021 01, Radon Daughter Concentration Work Sheet.

[24] Enge, W. (1980) Introduction to Plastic Nuclear Track Detectors. Nuclear Tracks and Radiation Measurements, 22, 283-308.

[25] Said, A.F., El Feky, M.G., El Galy, M.M. and El Mowafy, A.A. (2006) Application of Track Etch Detectors in U-Exploration at Abu-Zarab Area South West, Sinai, Egypt. The Egyptian Journal of Remote Sensing and Space Sciences, 9, 157-168.

[26] Stuckless, J.S., Nkomo, I.T., Winner, D.B. and Van Trump, G. (1984) Geochemistry and Uranium Favourability of the Post-Orogenic Granites of the North-Eastern Arabian Shield, Kingdom of Saudi Arabia. Journal of King Abdulaziz University: Earth Sciences, 6, 195-209.

[27] Rumyantsev, S. (1967) Industrial Radiology. Translated from the Russian by Semyonov, S., Mir Publishers, Moscow.

[28] Hassan, S.F. (2011) Radon Emanation and Radiation Hazards Indices for Sedimentary Rocks of WADI Abu-Mogherat Area, Sinai, Egypt. Journal of the Faculty of Education Ain shams University, 36/1A, 117-129.

[29] Korany, A.K. (2012) Uranium Concentrations at Different Depths Using Solid State Nuclear Track Detectors at Wadi Nasieb Area, Sinai, Egypt. MSc Thesis, Helwan University, Helwan, 160.

[30] UNSCEAR (1993) Sources and Effects of Ionizing Radiation. The United Nations, New York.

[31] EL-Taher, A. and AL-Zaharn, J.H. (2014) Radioactivity Measurements and Radiation Dose Assessments in Soil of Al-Qassim Region, Saudi Arabia. Indian Journal \& Applied Physics, 52, 147-154.

[32] UNSCEAR (1988) United Nations Scientific Committee on the Effect of Atomic Radiation, Sources, Effects and Risk of Ionizing Radiation. United Nations, New York.

[33] Stranden, E. (1976) Some Aspects on Radioactivity of Building Materials. Pyhsica Norvegica, 8, 167-177. 
[34] Krieger, R. (1981) Radioactive of Construction Materials. Betonwerk und Fertigteil Technik, 47, 468-473.

[35] Beretka, I. and Mathaw, P.I. (1985) Natural Radioactivity of Australian Building Materials, Industrial Wasts and By-Products. Health Physics, 48, 87-95. http://dx.doi.org/10.1097/00004032-198501000-00007

[36] Tufail, M., Ahmed, M., Shaib, S., Safdar, A., Mirza, N.M., Ahmed, N., Zafar, M.S. and Zafar, F.I. (1992) Investigation of Gamma-Ray Activity and Radiological Hazards of the Bricks Fabricated around Lahor, Pakistan. Pakistan Journal of Science and Industrial Research, 34, 216-220.

[37] Quindos, I.S., Fernandez, P.L. and Soto, J. (1987) Building Materials as Source of Exposure in House. In: Seifert, B. and Esdorn, H., Eds., Indoor Air'87, Volume 2, Institute for Water, Soil and Air Hygiene, Berlin, 365.

[38] Cottens, E. (1990) Actions against Radon at the International Level. Proceedings of the Symposium on SRBII, Journée Radon, Royal Society of Engineers and Industrials of Belgium, 17 January 1990, Brussels.

[39] ICRP (2000) Protection of the Public in Situations of Prolonged Radiation Exposure; ICRP Publication 82. Annals of the ICRP, 29.

[40] NEA-OECD (1979) Exposure to Radiation from Natural Radioactivity in Building Materials. Report by NEA Group of Experts. The Organization for Economic Cooperation and Development, Paris.

[41] Alam, M.N., Chowdhury, M.I., Kamal, M., Ghose, S., Matin, A.K.M.A. and Ferdousi, G.S.M. (1999) Radionuclide Concentrations in Mussels Collected from Southern Cost of Bangladesh. Journal of Environmental Radioactivity, 47, 201-212.

[42] El Shazly, E.M. and Hassan, M.A. (1972) Geology and Radioactive Mineralization at Wadi Sikait-Wadi El-Gemal Area, South Eastern Desert. Egyptian Journal of Geology, 16, 201.

[43] El Bayoumi, R.M.A. and Greiling, R. (1984) Tectonic Evolution of a Pan-African Plate Margin in Southwestern Egypt-A Suture Zone Overprinted by Low Angled Thrusting. In: Klerks, J. and Michot, J., Eds., Geologie Africaine, Africaine, Tervuren, 47-65.

[44] Abdel-Rahman, A.M. and Martin, R.F. (1990) The Mount Gharib A-Type Granite, Nubian Shield: Petrogenesis and Role of Metasomatism at the Source. Contributions to Mineralogy and Petrology, 104, 173-183. http://dx.doi.org/10.1007/BF00306441

[45] Barker, F., Farmer, G.L., Ayuso, R.A., Plafker, G. and Lull, J.S. (1992) The 50 Ma Granodiorite of the Eastern Gulf of Alaska: Melting in an Accretionary Prism in the Forearc. Journal of Geophysical Research, 97, 6757-6778. http://dx.doi.org/10.1029/92JB00257

[46] Brandon, A.D. and Lambert, R.St.J. (1994) Crustal Melting in the Cordilleran Interior: The Mid-Cretaceous White Creek Batholith in Southern Canadian Cordillera. Journal of Petrology, 35, 239-269. http://dx.doi.org/10.1093/petrology/35.1.239

[47] Maas, R., Nicholls, I.A. and Legg, C. (1997) Igneous and Metamorphic Enclaves in the S-Type Deddick Granodiorite, Lachlan Fold Belt, SE Australia: Petrographic, Geochemical and Nd-Sr Isotopic Evidence for Crustal Melting and Magma Mixing. Journal of Petrology, 38, 815-841. http://dx.doi.org/10.1093/petroj/38.7.815

[48] King, P.L., White, A.J.R., Chappell, B.W. and Allen, C.M. (1997) Characterization and Origin of Aluminous A-Type Granites from the Lachlan Fold Belt, Southeastern Australia. Journal of Petrology, 38, 371-391. http://dx.doi.org/10.1093/petroj/38.3.371

[49] Refaat, M. (2015): Determination of Subsurface Uranium Anomalies by Detecting Radon Emanated from Metamorphosed Sandstone in Wadi SiKait, Egypt, Using (SSNTD). MSc Thesis, Mansoura University, Mansoura, 100. 